\title{
The Effect of Maternal and Child Factors on Stunting in Children Under Five Years in Rural Indonesia
}

\section{Soffa Abdillah}

Department of Midwifery, Akademi Kebidanan Cianjur, West Java, Indonesia

\section{ORCID}

Soffa Abdillah: https://orcid.org/0000-0002-3486-5008

Corresponding Author: Soffa

Abdillah; email:

soffa.unjani@gmail.com

Published: 7 February 2022

Publishing services provided by

Knowledge E

(c) Soffa Abdillah. This article is distributed under the terms of the Creative Commons

Attribution License, which permits unrestricted use and redistribution provided that the original author and source are credited.

Selection and Peer-review unde the responsibility of the IVCN Conference Committee.

\section{G OPEN ACCESS}

Abstract. Indonesia has the fifth largest prevalence of stunting in the world. The results of the 2013 Basic Health Research showed that the prevalence of stunting in toddlers in Indonesia was 37.2\%. In Cianjur District, the prevalence of stunting in 2017 reached $35.7 \%$. The purpose of this study was to analyze the effect of maternal and child factors on stunting in children under five years in Cikancana, Cianjur District, in rural Indonesia. The study used an analytical design with a case-control approach. 42 mothers were included who had children under five years with stunting and 42 mothers who had healthy children. Data analysis was through the Chi-square test and multiple logistic regression. The results showed that, of the maternal factors, gestational weight gain and anemia during pregnancy were significantly related to stunting (both $p<0.001)$, while maternal height $(p=0.068)$ and maternal nutritional status during pregnancy $(p=0.801)$ were not significantly related to stunting. None of the child factors were significantly related to stunting, namely birth weight $(p=$ 1.000), birth length $(p=0.156)$, early breastfeeding initiation $(p=1.000)$, exclusive breastfeeding ( $p=0.175)$, complete basic immunization $(p=0.713)$, or history of infectious diseases $(p=1.000)$. Multiple logistic regression showed that anemia during pregnancy was the most influential factor for stunting in children under five years (OR 18.41; 95\% Cl 3.43-98.75; $\mathrm{p}<0.001$ ). Pregnant women need to be prepared by taking iron supplementation tablets during pregnancy so that anemia can be prevented.

Keywords: stunting, maternal factors, child factors

\section{Introduction}

Stunting, defined anthropometrically as height-for-age Z-score (HAZ) $<-2$ SD [1].Stunting is a chronic nutritional status that occurs since the beginning of the growth and development. According to World Health Organization (WHO), stunting can inhibit the development of children under five, such as intellectual decline, and susceptible to noncommunicable diseases[2].

Indonesia is a country with the fifth largest prevalence of stunting in the world. The results of the Basic Health Research in 2013 showed that the prevalence of stunting toddlers increased from $35.6 \%$ in 2010 to $37.2 \%$ in 2013 [3]. The results of the Nutrition 
Status Monitoring in children aged 0-59 months in 2016 showed a very short percentage of toddlers of $8.6 \%$ and short of $19.0 \%$ [4].

Stunting is generally caused by many factors, including: maternal factors and child factors. [5], classified stunting risk factors into five groups such as: maternal nutrition and infection; adolescent motherhood and short birth intervals; stunted fetal growth and premature birth; child nutrition and infection; and environmental factors.

Fetal growth depends on maternal nutrition. Inadequate energy and protein intake in pregnant women can cause Chronic Energy Deficiency (CED) which has an impact on fetal growth [6]. Baby factors that can trigger a toddler to become stunted are Low Birth Weight (LBW), length birth, and complete basic immunization [3]. In addition, children who are often exposed to infectious diseases will have an impact on growth [5].

Stunting may be reversed, especially if it occurs during the first two years of life. Of children stunted at 2 years of age, only $30 \%$ were no longer stunted at 8.5 years, and $32.5 \%$ were no longer stunted at 12 years [1]. Preventive actions can be included in the health program if modifiable factors related to stunting in early life can be identified. The controversy about predictors of stunting among previous studies suggests that demographic factors are likely to play an important role [1].

Cianjur District is included in the 10 (ten) priority districts in Indonesia for stunting reduction in the first quarter of 2018 with the prevalence of stunting in 2017 reaching $35.7 \%$. Therefore it is necessary to conduct research on the factors that influence stunting in Cianjur, especially in Cikancana Village, because this Village is one of the Priority Intervention Reduction Stunting Targets in Cianjur District [7]. Therefore, we aimed to analyze the effect of maternal and child factors on stunting among children under 5 years in Cikancana, Cianjur District, Rural Indonesia.

\section{Methods}

The study used analytic design with a case control approach. The independent variables in this study are maternal factors (maternal height, gestational weight gain , maternal nutritional status during pregnancy and anemia during pregnancy) and child factors (birth weight, length birth, early breastfeeding initiaton, exclusive breastfeeding, complete basic immunization, and history of infectious diseases). The independent variable is stunting.

The number of samples in this study were 84 people, 42 mothers who had stunting children under 5 years of age as a case, and 42 mothers who had normal children under 5 years as controls. Sampling technique using consecutive sampling. Analysis 
TABLE 1: Effect of Maternal Factors on Stunting

\begin{tabular}{|c|c|c|c|c|c|c|c|}
\hline \multirow[t]{2}{*}{ No. } & \multirow[t]{2}{*}{ Variable } & \multicolumn{2}{|c|}{ Stunting } & \multicolumn{2}{|c|}{ Normal } & \multirow{2}{*}{$\begin{array}{l}\mathrm{P} \\
\text { Value }\end{array}$} & \multirow[t]{2}{*}{ OR (Cl 95\%) } \\
\hline & & $n$ & $\%$ & $n$ & $\%$ & & \\
\hline \multirow[t]{3}{*}{1} & Maternal Height & & & & & & \\
\hline & $\leq 145 \mathrm{~cm}$ & 13 & 31 & 6 & 14.3 & 0.068 & $2.69(0.91-7.95)$ \\
\hline & $>145 \mathrm{~cm}$ & 29 & 69 & 36 & 85.7 & & \\
\hline \multirow[t]{3}{*}{2} & Gestational Weight Gain & & & & & & \\
\hline & $<\mathrm{BMI}$ recommendation & 34 & 81 & 15 & 35.7 & 0.000 & 7.65 (2.83-20.71) \\
\hline & $\geq \mathrm{BMI}$ recommendation & 8 & 19 & 27 & 64.3 & & \\
\hline \multirow[t]{3}{*}{3} & $\begin{array}{l}\text { Maternal Nutritional Status } \\
\text { During Pregnancy }\end{array}$ & & & & & & \\
\hline & CED (MUAC < $23.5 \mathrm{~cm})$ & 10 & 23.8 & 11 & 26.2 & 0.801 & $0.88(0.33-2.367)$ \\
\hline & Not CED (MUAC $\geq 23.5 \mathrm{~cm})$ & 32 & 76.2 & 31 & 73.8 & & \\
\hline \multirow[t]{3}{*}{4} & Anemia During Pregnancy & & & & & & \\
\hline & Anemia & 3 & 7.1 & 17 & 40.5 & 0.000 & $0.11(0.03-0.43)$ \\
\hline & Not anemia & 39 & 92.9 & 25 & 59.5 & & \\
\hline
\end{tabular}

used bivariate analysis with chi square and multivare analisys with multiple logistic regression. Sampling was carried out in the village of Cikancana, Cianjur Regency. The instrument for collecting data uses a questionnaire. Child's nutritional status is measured using height-for-age Z-score (HAZ).

\section{Results}

\subsection{Effect of Maternal Factors on Stunting}

Table 1. showed that gestational weight gain $(p=0.000)$ and anemia during pregnancy were significantly related to stunting $(p=0.000)$. While maternal height $(p=0.068)$, and maternal nutritional status during pregnancy $(p=0.801)$ were not significantly related to stunting.

\subsection{Effect of Child Factors on Stunting}

Table 2. shows that based on the result of the bivariate analysis on child factors: birth weight ( $p=1.000)$; birth length ( $p=0156)$; early breastfeeding initiation $(p=1.000)$; exclusive breastfeeding $(p=0.175)$; complete basic immunization $(p=0.713)$, and history of infectious diseases $(p=1.000>0.05)$ were not significantly related to stunting. 
TABLE 2: Effect of Child Factors on Stunting

\begin{tabular}{|c|c|c|c|c|c|c|c|}
\hline \multirow[t]{2}{*}{ No. } & \multirow[t]{2}{*}{ Variable } & \multicolumn{2}{|c|}{ Stunting } & \multicolumn{2}{|c|}{ Normal } & \multirow{2}{*}{$\begin{array}{l}\text { P } \\
\text { Value }\end{array}$} & \multirow[t]{2}{*}{ OR (Cl 95\%) } \\
\hline & & $n$ & $\%$ & $\mathrm{n}$ & $\%$ & & \\
\hline \multirow[t]{3}{*}{1} & Birth Weight & & & & & & \\
\hline & $<2500$ gram & 2 & 4.8 & 1 & 2.4 & 1.000 & $2.050(0.179-23.512)$ \\
\hline & $\geq 2500$ gram & 40 & 95.2 & 41 & 97.6 & & \\
\hline \multirow[t]{3}{*}{2} & Birth Length & & & & & & \\
\hline & $<48 \mathrm{~cm}$ & 7 & 16.7 & 2 & 4.8 & 0.156 & $4.000(0.779-20.531)$ \\
\hline & $\geq 48 \mathrm{~cm}$ & 35 & 83.3 & 40 & 95.2 & & \\
\hline \multirow[t]{3}{*}{3} & Early Breastfeeding Initiation & & & & & & \\
\hline & Not Early Initiation & 5 & 11.9 & 4 & 9.5 & 1.000 & $1.284(0.320-5.157)$ \\
\hline & Early Initiation & 37 & 88.1 & 38 & 90.5 & & \\
\hline \multirow[t]{3}{*}{4} & Exclusive Breastfeeding & & & & & & \\
\hline & Not Exclusive & 11 & 26.2 & 6 & 14.3 & 0.175 & $2.129(0.705-6.425)$ \\
\hline & Exlucive & 31 & 73.8 & 36 & 85.7 & & \\
\hline \multirow[t]{3}{*}{5} & Complete Basic Immunization & & & & & & \\
\hline & Not Complete & 3 & 7.1 & 5 & 11.9 & 0.713 & $0.569(0.127-2.552)$ \\
\hline & Complete & 39 & 92.9 & 37 & 88.1 & & \\
\hline \multirow[t]{3}{*}{6} & History of Infectious Diseases & & & & & & \\
\hline & There is infectious diseases & 37 & 88.1 & 38 & 90.5 & 1.000 & $0.779(0.194-3.129)$ \\
\hline & $\begin{array}{l}\text { There is no infectious } \\
\text { diseases }\end{array}$ & 5 & 11.9 & 4 & 9.5 & & \\
\hline
\end{tabular}

\subsection{Multivariate Analysis}

Based on the result of the final model shown in table 3, it can be seen that weight gain during pregnancy, anemia during pregnancy and length birth affect stunting. Women with weight gain during pregnancy < BMI recommendation were 0.09 times more likely to have stunted child compared with those who gain weight during pregnancy $\geq$ BMI recommendation (OR: $0.09,95 \% \mathrm{Cl}(0.03-0.28)$ ), women who have anemia during pregnancy were 18.4 times more likely to have stunted child compared with those who did not have anemia during pregnancy (OR: 18.40, 95\% Cl (3.43-98.75)), and children born with birth length $<48 \mathrm{~cm} 0.05$ times more likely becoming stunted compared to children born with birth length $\geq 48 \mathrm{~cm}$ (OR: 0.05, 95\% $\mathrm{Cl}(0.00-0.60)$ ). It can be concluded that anemia during pregnancy were the most dominant factor for stunting among children under 5 years .

\section{Discussion}


TABLE 3: The Strong Determinants Affecting Stunting Among Children Under 5 Years Of Age

\begin{tabular}{l|l|l|l|l} 
Variable & Koef B & SE ( $\beta)$ & P Value & OR (Cl 95\%) \\
\hline Weight Gain During Pregnancy (1) & -2.465 & 0.605 & 0.000 & $0.09(0.03-0.28)$ \\
\hline Anemia During Pregnancy (1) & 2.912 & 1.264 & 0.001 & $18.40(3.43-98.75)$ \\
\hline Birth Length (1) & -2.990 & 0.471 & 0.018 & $0.05(0.00-0.60)$
\end{tabular}

\subsection{Effect of Maternal Factors on Stunting}

\subsection{Maternal Height}

Maternal height was not related to stunting in this study. The result of this study are in line with the research of Prawihartono et al. (2016), that maternal height $(<145 \mathrm{~cm})$ was also not a prognostic factor for stunting. In Contrast, a Cambodian study showed that maternal height was a significant risk factor for stunting status of the child. Short maternal height correlated with intrauterine growth retardation and low birth weight, which are potential predictors of infant mortality and failure to thrive. [2] found in West Java Indonesia concluded that for every $1 \mathrm{~cm}$ increase in maternal height, the infant's body length increased by $0.196 \mathrm{~cm}(p=0.000$. Women with a height $<145 \mathrm{~cm}$ during early pregnancy are at greater risk of delivering a small for gestational age (SGA) infant [8].

\subsection{Gestational Weight Gain}

Maternal factors during pregnancy also determine the length of the baby's birth. The result of this study showed that Gestational weight gain were significantly related to stunting $(p=0.000<0.05)$. Gestational weight gain affects the length of the baby's birth. Babies with short birth lengths have a history of weight gain during pregnancy that is below standard compared to babies born with normal birth lengths [6]. [9] study in Guatemala showed that Maternal weight gain from the first to the second trimester was associated with fetal femur and tibia lengths measured at both means of 17 and $30 \mathrm{wk}$ $(P<0.05)$ and infant length at birth $(P<0.001$. There is a complex association between maternal nutrient deficiency and fetal growth. In undernourished mothers, a series of metabolic responses to insufficient energy and protein availability result in a less-thanadequate exchange of nutrients between the mother and the fetus [9]. Relation between weight gain from the first to the second trimester and fetal linear growth reflect better placental nutrient transport and a better supply of endocrine growth factors in women who gain more weight [9]. 


\subsection{Maternal Nutritional Status During Pregnancy}

Maternal nutritional status during pregnancy is based on the Mid Upper Arm Circumference (MUAC). Pregnant women with MUAC $<23.5 \mathrm{~cm}$ are included in the Chronic Energy Deficiency (CED) category. Pregnant women with poor maternal nutrition would result in low birth weight infants. Intrauterine malnutrition caused developmental deficits that could lead to a reduction in the energy requirements with changes in the regulation of the endocrine system [10]. These changes are needed to support life in the beginning, and in the long term this will have harmful effect because they occur at the expense of growth reduction, making short height an important indicator of long-term nutritional disorder [11]. However our study showed that maternal nutritional status during pregnany were not related to stunting. This might happen because there are many other factors that cause stunting.

\subsection{Anemia During Pregnancy}

Pregnant women with anemia have an impact on fetal growth and development. The result of this study showed that anemia during pregnancy was significantly related to stunting $(p=0.000<0.05)$. Micronutrient deficiency role in fetal growth has been the topic of many recent studies and reviews, the results of which implicate the deficiency of many micronutrients (eg, zinc, iron, iodine, and folate) in fetal growth retardation [9].Pregnant women who are exposed to anemia result in reduced oxygen supply to the body's cells and brain, causing symptoms of fatigue, lethargy, and appetite disorders, thus affecting the nutritional condition of the mother, which is reflected in her weight [12]. The low status of some biochemical parameters of the subject during pregnancy is thought to be related to the low intake of maternal protein during pregnancy. Hemoglobin is a blood pigment that is red in color and functions as a carrier of oxygen and carbon dioxide consisting of protein binding components [13].

\subsection{Effect of Child Factors on Stunting}

\subsubsection{Birth Weight}

Low birth weight was reported to be a risk factor for stunting. Birth weight has a large impact on a child's growth, child development and height as an adult. Children born with low birth weight had a risk of neurological abnormalities that led to poor growth. Babies born with a low birth weight will be at high risk of mordibity, death, infectious diseases, 
underweight and stunting at the beginning of the neonatal period until childhood. This is consistent with the results of research conducted by [3], that toddlers with low birth weight have a risk of experiencing stunting 5.250 times greater than toddlers with normal birth weight. In contrast with Elba's study, our results showed that there's no significant relationship between low birth weight with stunting.

\subsubsection{Birth Length}

Baby's short body length at birth is influenced by the lack nutrition while still in intrauterin. Nonetheless, our study results show that length birth is not related to stunting. In contrast, Swathma's et al. (2017) research results show OR 4.078, meaning that respondents who have toddlers with short body length at birth have a risk of experiencing stunting 4.078 times greater than respondents who have toddlers with normal body length at birth.

\subsubsection{Early Breastfeeding Initiation}

Breastfeeding Early Initiation is breastfeeding that starts shortly after birth usually within the first hour. Breast milk that comes out in the first days of birth contains colostrum. Colostrum is rich in antibodies and substances important for intestinal growth and resistance to infections that are needed by the baby for survival [11]. Our study showed that early breastfeeding initation were not related to stunting ( $p=1.000)$. In contrast, [14] study in Indonesia showed that early breastfeeding initiation had a significant correlation with the stunting ( $p$-value $<0.05$ ). The children who did not get the early breastfeeding initiation have the 3.69 more likely to suffer from stunting than those who got the early breastfeeding initiation.

\subsubsection{Exclusive Breastfeeding}

Another factor related to stunting is exclusive breastfeeding. Exclusive breastfeeding can increase height growth in children.Our study results show that the length of the birth is not related to stunting $(p=0.175)$. The results of this study different from studies in Bangladesh which conclude there is a positive relationship between breastfeeding and increased growth in children's height [14]. Research in Southern Ethiopia also proves that toddlers who do not get exclusive breastfeeding for six months have a high risk of stunting. Exclusive breastfeeding can prevent stunting or failure to grow [14]. The content 
of lactoferrin in breast milk binds iron function to inhibit the growth of bacteria, other than that the enzyme peroxidase in breast milk can destroy pathogenic bacteria. Breast milk produces the protein TGF $\beta$ (Transforming Growth Factor Beta) which will balance pro-inflammatory and anti-inflammatory properties so that the intestine can function normally [14].

\subsubsection{Complete Basic Immunization}

Complete Basic Immunization was not related to stunting in this study ( $p=0.713$ ). In contrast [11] study, obtained an OR 6,044, meaning that respondents who had a toddler with a history of incomplete basic immunization had a risk of experiencing stunting 6.044 times greater than those who had a toddler with a history of complete basic immunization. Immunization provides children with protection from disease infection, so the child will stay healthy and not get sick easily.

\subsubsection{History of Infectious Diseases}

Infectious diseases have effects on children's growth and development. The more often the child is infected, the growth will be more disrupted. The results of this study indicate that the history of infectious diseases is not related to stunting. In contrast, Studies in India found an association between diarrhea and stunting. The causal pathway is through enteropathy, which is damage to the digestive system. Because of recurring pain, there will be a thickening of the area of the crypt in the small intestine and reduce the absorption of nutrients, also the villi (organs such as protrusions on the surface in the small intestine) become flat and reduce the absorption of nutrients so that nutrients are not absorbed into the digestive tract [10]).

\subsection{Multivariate Analysis}

Test analysis using multiple logistic regression analysis shows that weight gain during pregnancy, anemia during pregnancy and length of birth are factors that influence the incidence of stunting. Based on the results of logistic regression analysis it can be concluded that anemia during pregnancy is the most influential factor in the incidence of stunting with an OR value of 18.41 (95\% $\mathrm{Cl}$ (3.43-98.75)). This means that women who have anemia during pregnancy were 18.4 times more likely to have stunted children compared to those who did not have anemia during pregnancy. Our study showed 
results that the origin of stunting is during the fetal stage of life. The life of the fetus in intrauterine has an important role in the nutritional status of children after birth. Every pregnant woman requires adequate nutrition so that fetal growth can be optimal.

\section{Conclusion}

Stunting is a nutritional problem that occurs chronically, one of the causes of stunting is the maternal and child factors. The result of this study showed that maternal factors (weight gain and anemia during pregnancy) were related to stunting. Multiple logistic regression showed that anemia during pregnancy were the most dominant factor for stunting among children under 5 years.

Pregnant woman needs to be adequately prepared so there is no anemia during pregnancy and she can gain weight according to BMl's recommendation, because the results of this study indicate that intrauterine life has a role in the risk of stunting. Pregnant woman also need iron (Fe) supplement during pregnany so that anemia can be prevented. Health workers need to monitor the nutritional status regular.,ly and periodically so that stunting can be identified as early as possible. More research is needed to explore the effect of maternal and child factors among children under 5 years.

\section{Competing interest}

The authors declare that they have no competing interests.

\section{Funding}

No Funding for this research.

\section{Acknowledgement}

Special thanks to all participants and for Akademi Kebidanan Cianjur for the support.

\section{References}

[1] Prawirohartono E, Nurdiati D, Hakimi M. Prognostic factors at birth for stunting at 24 months of age in rural Indonesia. Paediatrica Indonesiana. 2016;56:48-56. 
[2] Ni'mah K, Nadhiroh SR. Factors associated with the incidence of stunting in infants. Media Gizi Indonesia. 2016;10:13-19.

[3] Elba F, Marheni D, Dhamayanti M, et al. Factors affecting the incidence of stunting in toddlers age 24-36 months in Batujajar district, West Bandung, Indonesia. Jurnal Pendidik dan Pelayanan Kebidanan Indonesia. 2015;2:9-16.

[4] Prabandari Y, Hanim D, Ar RC, et al. Hubungan kurang energi kronik dan anemia pada ibu hamil dengan status gizi bayi usia 6-12 bulan di kabupaten boyolali (correlation chronic energy deficiency and anemia during pregnancy with nutritional status of infant 6-12 months in Boyolali regency). Nutrition and Food Research. 2016;39:1-8.

[5] Danaei G, Andrews KG, Sudfeld CR, et al. Risk factors for childhood stunting in 137 developing countries: A comparative risk assessment analysis at global, regional, and country levels. PLoS Medicine. 2016;13:1002164.

[6] Trihono T, Atmarita A, Tjandrarini DH, et al. Short (stunting) in Indonesia, problems and solutions. Lembaga Penerbit Badan Litbangkes; 2015.

[7] Dinas Kesehatan Kabupaten Cianjur. Holistic intervention of integrative stunting countermeasures.

[8] Beal T, Tumilowicz A, Sutrisna A, et al. A review of child stunting determinants in Indonesia. Maternal and Child Nutrition. 2018;14:12617.

[9] Neufeld LM, Haas JD, Grajéda R, et al. Changes in maternal weight from the first to second trimester of pregnancy are associated with fetal growth and infant length at birth. The American journal of clinical nutrition. 2004;79:646-652.

[10] Sawaya AL, Roberts S. Stunting and future risk of obesity: Principal physiological mechanisms. Cadernos de saúde pública. 2003;19:S21-S28.

[11] Silveira KBR, Alves JFR, Ferreira HS, et al. Association between malnutrition in children living in favelas, maternal nutritional status, and environmental factors. J Pediatr (Rio J). 2010;86:215-220.

[12] Ruaida N, Nurdiati DS. The relationship between anemia in pregnant women and the incidence of stunting in children aged 6-24 months in Yogyakarta City.

[13] Ernawati F, Rosamalina Y, Permanasari Y. Effect of the pregnant women's protein intake and their baby length at birth to the incidence of stunting among children. Nutrition and Food Research. 2013;36:1-11.

[14] Permadi MR, Hanim DK, Indarto D. Risiko inisiasi menyusu dini dan praktek ASI eksklusif terhadap kejadian stunting pada anak 6-24 bulan. Penelit Gizi dan Makanan. 2016;39:9-14. 